\title{
Procaspase 3/p21 complex formation to resist Fas-mediated cell death is initiated as a result of the phosphorylation of p21 by protein kinase $A$
}

\author{
A Suzuki ${ }^{*}$,, H Kawano ${ }^{1}$, M Hayashida ${ }^{1}$, Y Hayasaki ${ }^{2}$, \\ Y Tsutomi ${ }^{2}$ and $K$ Akahane $^{3}$ \\ 1 Project for the Cell Death Research, Basic Technology Research Laboratory, \\ Daiichi Pharmaceutical Co., Ltd., Tokyo R\&D Center, Kitakasai 1-16-13, \\ Edogawa-ku, Tokyo 134-8630, Japan \\ 2 Drug Safety Research Laboratory, Daiichi Pharmaceutical Co., Ltd., Tokyo \\ R\&D Center, Kitakasai 1-16-13, Edogawa-ku, Tokyo 134-8630, Japan \\ ${ }^{3}$ New Product Research Laboratories IV, Daiichi Pharmaceutical Co., Ltd., \\ Tokyo R\&D Center, Kitakasai 1-16-13, Edogawa-ku, Tokyo 134-8630, Japan \\ * Corresponding author: A Suzuki, Project for the Cell Death Research, Basic \\ Technology Research Laboratory, Daiichi Pharmaceutical Co., Ltd., Tokyo \\ R\&D Center, Kitakasai 1-16-13, Edogawa-ku, Tokyo 134-8630, Japan. \\ Tel: +81-3-5696-9167; Fax: +81-3-5696-8336; E-mail: LEB00373@nifty.ne.jp
}

Received 18.11.99; revised 4.2.00; accepted 4.4.00

Edited by $\mathrm{P}$ Golstein

\begin{abstract}
Caspase 3 is an essential factor for Fas-mediated cell death and exists endogenously in cells where its activation is suppressed by p21 and ILP. Inside the cell, procaspase 3 interacts with p21 on mitochondria. In the present study, we investigated the molecular basis for procaspase 3/p21 complex formation. During Fas-mediated cell death, mitochondria are damaged, accompanied by decreased mitochondrial membrane-potential and decreased intracellular ATP levels. This mitochondrial damage occurs before an estrangement of the procaspase $3 /$ p21 complex, and we demonstrate that intracellular ATP-deprivation also initiates an estrangement of procaspase 3/p21 complex formation and accelerates Fas-mediated cell death. In addition, our current results revealed that the phosphorylated p21 by PKA interacts with procaspase 3. Here, we report that the mitochondrial role, especially for ATP synthesis, and PKA are necessary for the procaspase 3/p21 complex formation to resist Fas-mediated cell death. Cell Death and Differentiation (2000) 7, 721-728.
\end{abstract}

Keywords: intracellular ATP; procaspase 3/p21 complex; Fasmediated cell death; mitochondria; PKA

Abbreviations: adenosine triphosphate: ATP; protein kinase A: PKA; agonistic anti-human Fas antibody $\mathrm{CH}-11$ clone: Fas Ab; $5^{\prime}$-pfluorosulfonylbenzoyl adenosine: FSBA

\section{Introduction}

Cell death is an essential phenomenon for cell homeostasis, as well as cells growth, and has been well documented during embryonic and postembryonic development. ${ }^{1,2}$ There are two distinct processes leading to cell death known as apoptotic cell death and necrotic cell death. ${ }^{1}$ Apoptotic cell death is accompanied by the condensation and/or fragmentation of nuclei, apoptotic body formation and chromosomal DNA fragmentation into $180 \mathrm{bp}$ oligomers. ${ }^{1}$ Multiple studies have demonstrated the important role of apoptotic cell death in various disease states and physiological cell death ${ }^{3}$ and many factors involved with the death signaling have been identified.

The cell surface protein Fas transduces cell death signaling upon stimulation by the Fas ligand. ${ }^{3}$ At the down stream portion of the cell death signaling transduced by the Fas ligand/Fas system, caspase acts as the essential regulator $^{2}$ and is the nomenclature for the interleukin- $1 \beta$ converting enzyme (ICE)/CED-3 cysteine proteinase family member. ${ }^{4}$ To date, 14 genes have been identified within the caspase family, and three subfamilies have been identified, known as the ICE subfamily, CPP32 subfamily and ICH-1 subfamily. ${ }^{4}$ The CPP32 subfamily, including caspase 3 (CPP32/Yama/Apopain), is the most important factor for Fas-mediated cell death. ${ }^{5}$ Activation of caspase 3 is regulated by a cytoplasmic serine proteinase ${ }^{6}$ and another CPP32 subfamily member, caspase 8 (FLICE/MACH and see $^{7-9}$ ).

Caspase 3 is expressed endogenously in cells, ${ }^{5}$ and we recently demonstrated that its activation is suppressed by two factors. Procaspase 3 interacts with the cell cycle regulator p21 through its $\mathrm{NH}_{2}$-terminal sequence on mitochondria. ${ }^{10-12}$ Caspase 3 is inactivated as a result of masking its p3-cleavage site. ${ }^{11}$ In addition, activated caspase 3 is inactivated by the IAP family member ILP. ${ }^{10,11,13,14}$ Through this two step mechanism, caspase 3 is inactivated endogenously in cells.

Recently, some molecular machinery have been reported as the cell-survival system. Protein kinase B member Akt phosphorylates and inactivates the Bcl-2 family member Bad which acts as the death accelerator. ${ }^{15,16}$ Akt also phosphorylates the caspase 9 (ICE/LAP6/Mch6/APAF-3) to induce cell survival. ${ }^{17}$ In addition, it has been recently reported that protein kinase $A$ also induce cell survival as a result of the phosphorylation of Bad. ${ }^{18}$ Thus, cell survival as a result of the phosphorylation of death-associated factors by protein kinases has recently studied well.

As indicated above, we have reported about caspase 3 inactivation system. Caspase 3 interacts with p21 with each $\mathrm{NH}_{2}$ amino acid sequence to resist Fas-mediated cell death. This procaspase $3 / \mathrm{p} 21$ complex formation is initiated under the influence of mitochondrion. It is of interest that mitochondria act for the cell survival (resistance to cell death signaling), however, we could not identify what factor(s) derived from mitochondrion is necessary for the procaspase $3 /$ p21 complex formation to resist Fas-mediated cell death in our 
previous report. In the present study, therefore, we investigated what factor(s) is required for the procaspase 3/ p21 complex formation on mitochondria. We report that cellular ATP synthesized by mitochondria and protein kinase $A$ are necessary for the procaspase 3/p21 complex formation.

\section{Results}

\section{Caspase-3 and mitochondrial function during Fas-mediated cell death}

To investigate biochemical events on mitochondria during Fas-mediated cell death, mitochondrial function was examined. As a first approach, intracellular ATP was measured. When HepG2 cells were treated with antagonistic Fas antibody (Fas $A b$ ) in the presence of actinomycin $D$, cells showed a decrease in the level of intracellular ATP within $6 \mathrm{~h}$ (Figure 1A). In addition, mitochondrial membrane potential, which is generally used to assess mitochondrial viability, was measured using Rhodamine 123. Mitochondrial membrane potential was also decreased by $\mathrm{Fas} A b$ and actinomycin $\mathrm{D}$ co-treatment within $6 \mathrm{~h}$ (Figure 1B). In contrast, Fas Abinduced caspase 3 activation was not induced significantly within $12 \mathrm{~h}$, and it showed a peak level at $16 \mathrm{~h}$ after Fas $\mathrm{Ab}$ treatment (Figure 1C). Thus, this data suggests that mitochondrial damage preceded Fas-mediated cell death.

\section{Effect of intracellular ATP-deprivation in Fas-mediated cell death}

Intracellular ATP-deprivation was induced by treatment for $2 \mathrm{~h}$ with oligomycin or 5'-p-fluorosulfonylbenzoyl adenosine
(FSBA) (Figure 2A). However, these treatments alone did not induce cell death or caspase 3 activation (Figure 2A). Fasmediated cell death and caspase 3 activation could be induced by Fas $A b$ in the presence of actinomycin $D$, but were not suppressed by the intracellular ATP-deprivation triggered by oligomycin or FSBA (Figure $2 \mathrm{~B}$ ).

Ordinarily, HepG2 cells do not show Fas-mediated cell death in the absence of actinomycin D. ${ }^{10-12}$ Interestingly, however, additional studies revealed that intracellular ATPdeprivation did not require actinomycin $D$ for the induction of Fas-mediated cell death and caspase 3 activation (Figure 3). HepG2 cells pretreated with oligomycin or FSBA showed Fas-mediated cell death and caspase 3 activation by Fas $\mathrm{Ab}$ alone.

\section{Procaspase 3/p21 complex formation requires intracellular ATP}

HepG2 cells show resistance to Fas-mediated cell death as a result of caspase 3 inactivation by p21 on mitochondria. ${ }^{10-12}$ Our current works reveals that HepG2 cells treated to reduce intracellular ATP-levels are no longer resistant. Therefore, we examined the effect of intracellular ATP-deprivation on procaspase 3/p21 complex formation. When cells were treated with oligomycin or FSBA, expression of procaspase 3 and p21 was observed, but the procaspase 3/p2 complex was not detected in immunoprecipitates (Figure 4).

\section{Effect of protein kinase A in Fas-mediated cell death}

Our current results suggest that intracellular ATP is involved with the resistance to Fas-mediated cell death, namely
A

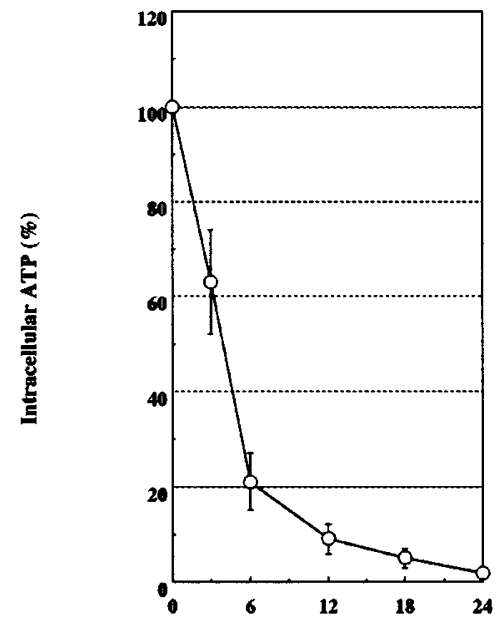

Time (hour)
B

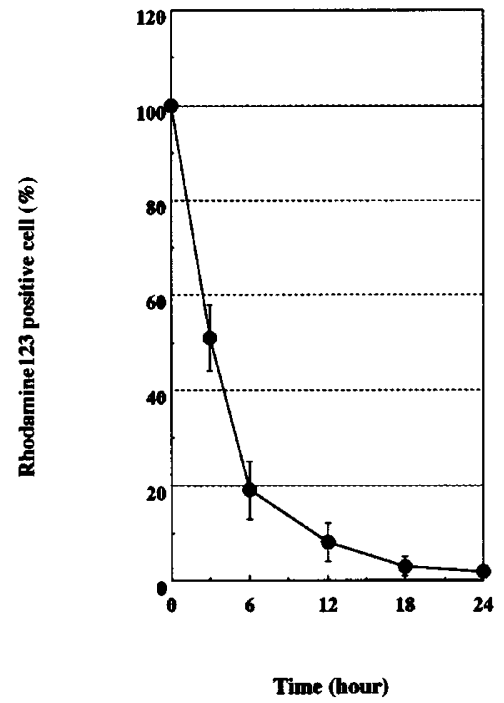

C

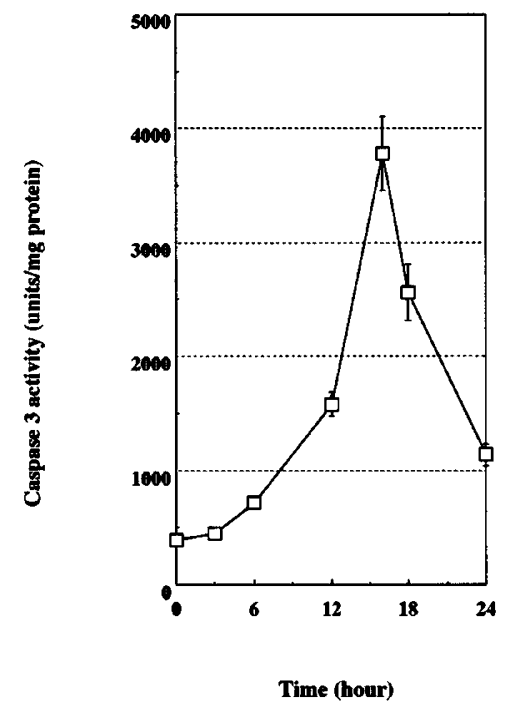

Figure 1 Mitochondrial damage during Fas-mediated cell death. HepG2 cells were treated with $1 \mu \mathrm{g} / \mathrm{ml}$ agonistic anti-human Fas antibody (CH-11 clone and se $^{39}$ ) in the presence of $0.5 \mu \mathrm{g} / \mathrm{ml}$ actinomycin D. At each treatment time, cells were collected and intracellular ATP level (A), mitochondrial membrane potential (B) and caspase 3 activity (C) were measured. Intracellular ATP was measured with intracellular ATP-measure kit (Wako Pure Chemical, Osaka, Japan), mitochondrial membrane potential was measured as the rate of Rhodamine 123-staining using Flowcytometer, and caspase-3 activity was measured as the DEVDMCA cleavage. Bars are standard error of five independent samples 
A
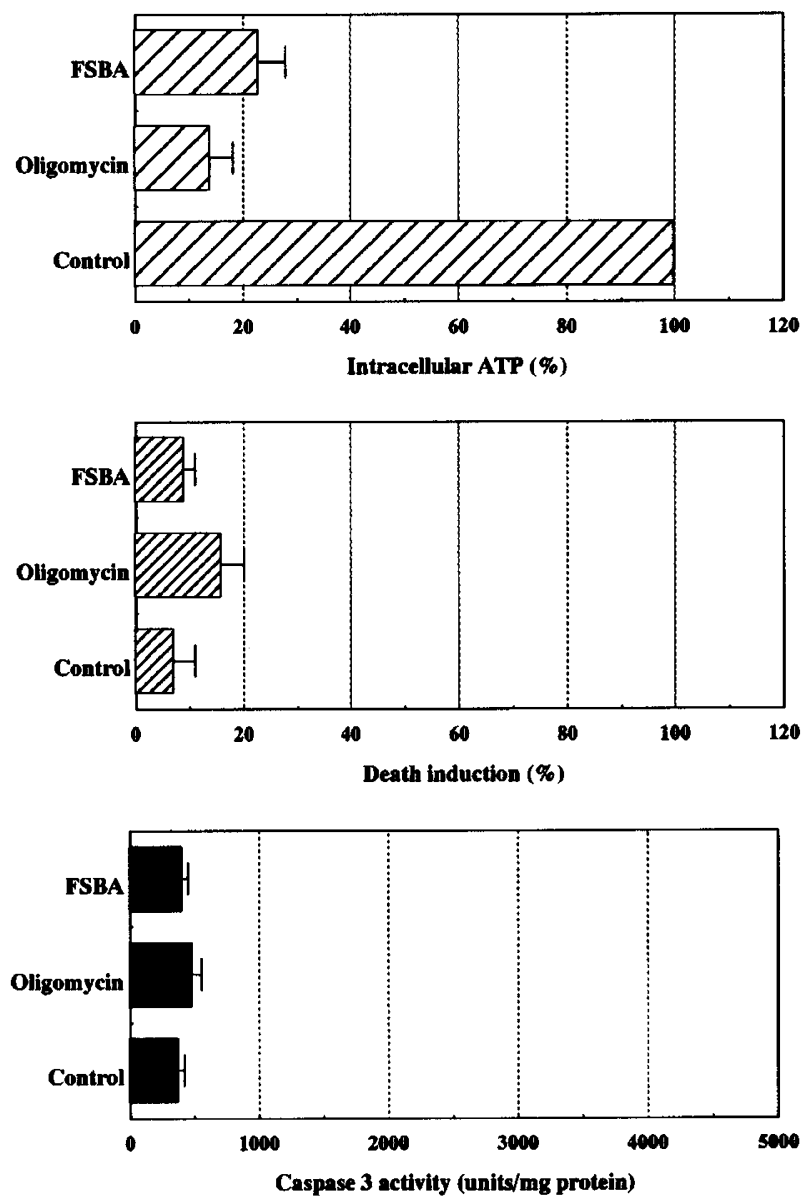

B

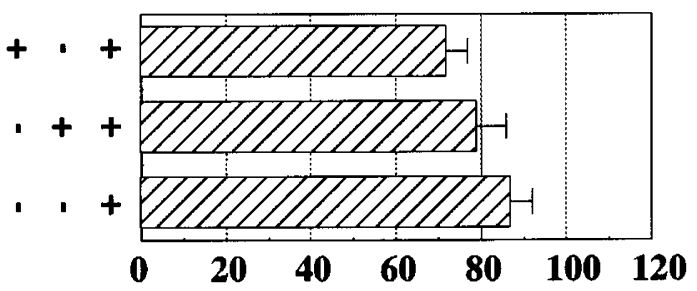

Death induction (\%)
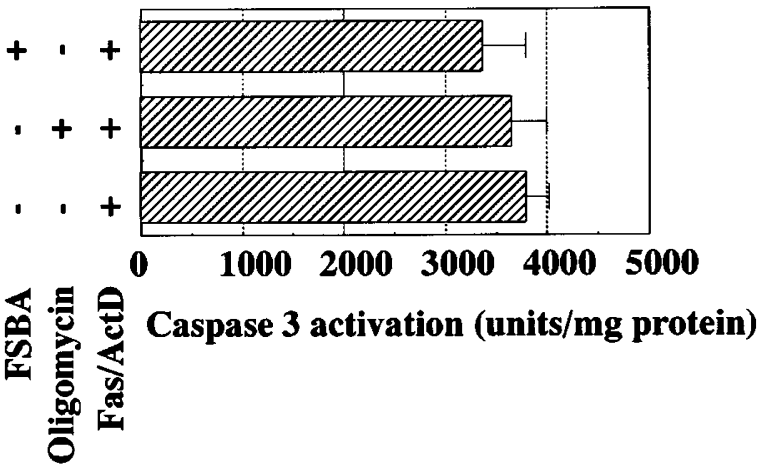

Figure 2 Effect of intracellular ATP-deprivation on Fas-mediated cell death. (A) Intracellular ATP-deprivation was induced by the treatment with $10 \mu \mathrm{M}$ oligomycin or $100 \mu \mathrm{M}$ FSBA for $2 \mathrm{~h}$. After treatment, intracellular ATP (upper), cell death induction (Hoechst 33342/PI staining analysis: middle) and caspase 3 activity (DEVDMCA cleavage: lower) were examined. Bars are standard error of five independent samples. (B) HepG2 cells pretreated with $10 \mu \mathrm{M}$ oligomycin or $100 \mu \mathrm{M}$ FSBA for $2 \mathrm{~h}$, were treated with $1 \mu \mathrm{g} / \mathrm{ml}$ agonist Fas Ab for $24 \mathrm{~h}$ (Death induction: upper) or $16 \mathrm{~h}$ (Caspase 3 activation: lower) in the presence of $0.5 \mu \mathrm{g} / \mathrm{ml}$ actinomycin $\mathrm{D}$. After treatment, cells were collected, and then the rate of death induction or caspase 3 activity were measured with Hoechst $33342 / P I$ staining analysis or DEVD-MCA cleavage. Bars are standard error of five independent samples

procaspase 3/p21 complex formation. Therefore, we examined whether protein kinases are necessary for the procaspase 3/p21 complex formation. Fas-mediated cell death in HepG2 cells triggered by co-treatment of Fas $A b$ and actinomycin $D$ was not suppressed by protein kinaseinhibitors used for our current study (Table 1). However, only protein kinase $A$ (PKA) inhibitor $\mathrm{H} 8$ showed the death induction with Fas $A b$, instead of actinomycin $D$ (Table 1 and Figure 5). In addition, $\mathrm{H} 8$ treatment induced the estrangement of procaspase 3/p21 complex formation (Figure 6).

Thus, the phosphorylation by PKA is involved with the procaspase 3/p21 complex formation to resist Fasmediated cell death, and our further experiments revealed that PKA phosphorylated p21, but not procaspase 3 , to initiate procaspase 3/p21 complex formation (Figure 7).

\section{Discussion}

Caspase family members are necessary for cell death signaling. ${ }^{4}$ In particular, caspase 3 (CPP32/Yama/Apopain) is the most important factor for the Fas-mediated cell death. ${ }^{5}$ Caspase 3 endogenously exists in cells, but it is not activated until Fas stimulation, ${ }^{5}$ suggesting the possible presence of a caspase 3 inactivation system. Human hepatoma HepG2 cells express Fas on their cell surface and show Fasmediated cell death by agonist Fas Ab only in the presence of de novo protein synthesis inhibitor (transcriptional inhibitor) actinomycin D..$^{5,10-12}$ Thus, HepG2 cells show resistance to Fas-mediated cell death if the cells are not pretreated with actinomycin D. Recently, we demonstrated that caspase 3 was inactivated by p21 or ILP in HepG2 cells. ${ }^{10}$

The role of mitochondria during cell death induction has recently been a focus. ${ }^{19}$ Mitochondria show down-regulation 


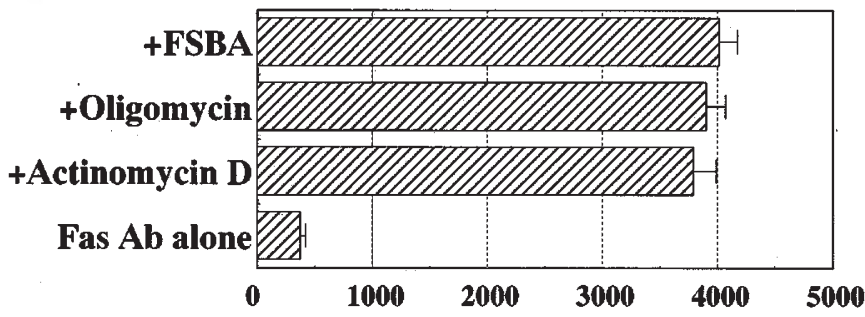

Caspase 3 activation (units/mg protein)
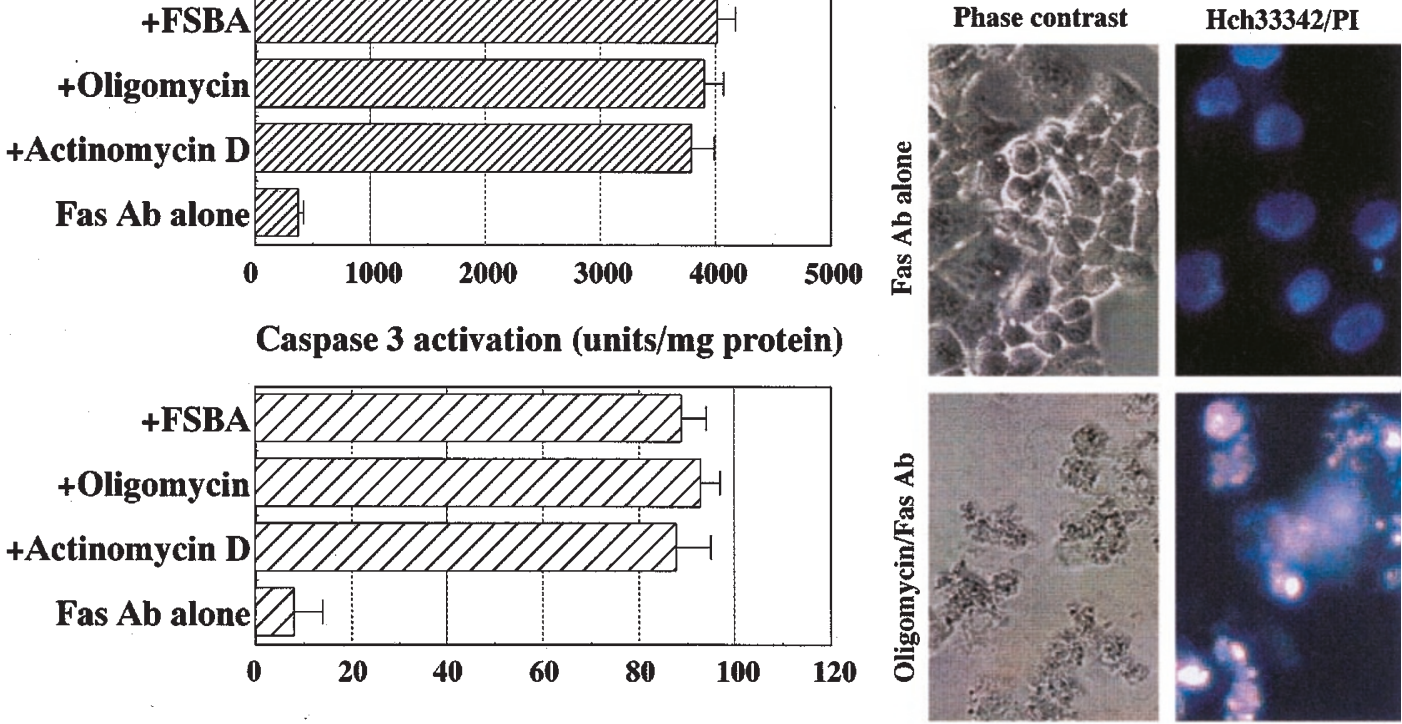

Death induction (\%)

Figure 3 Effect of intracellular ATP-deprivation on the resistance to Fas-mediated cell death. HepG2 cells pretreated with $10 \mu \mathrm{M}$ oligomycin (+Oligomycin) or $100 \mu \mathrm{M}$ FSBA (+FSBA) for $2 \mathrm{~h}$ were treated with $1 \mu \mathrm{g} / \mathrm{ml}$ Fas Ab for $24 \mathrm{~h}$ (Death induction: lower graph) or $16 \mathrm{~h}$ (Caspase 3 activation: upper graph) in the absence of actinomycin D. In this experiment, cells treated with Fas Ab alone or Fas Ab and actinomycin D combination (+Actinomycin D) were also examined. Bars are standard error of five independent samples. Fas-mediated cell death in the absence of actinomycin D in HepG2 cells pretreated with (lower photograph) or without (upper photograph) oligomycin was analyzed by phase-contrast (left photograph) or fluorescence (right photograph: Hoechst 33342/PI) microscopy
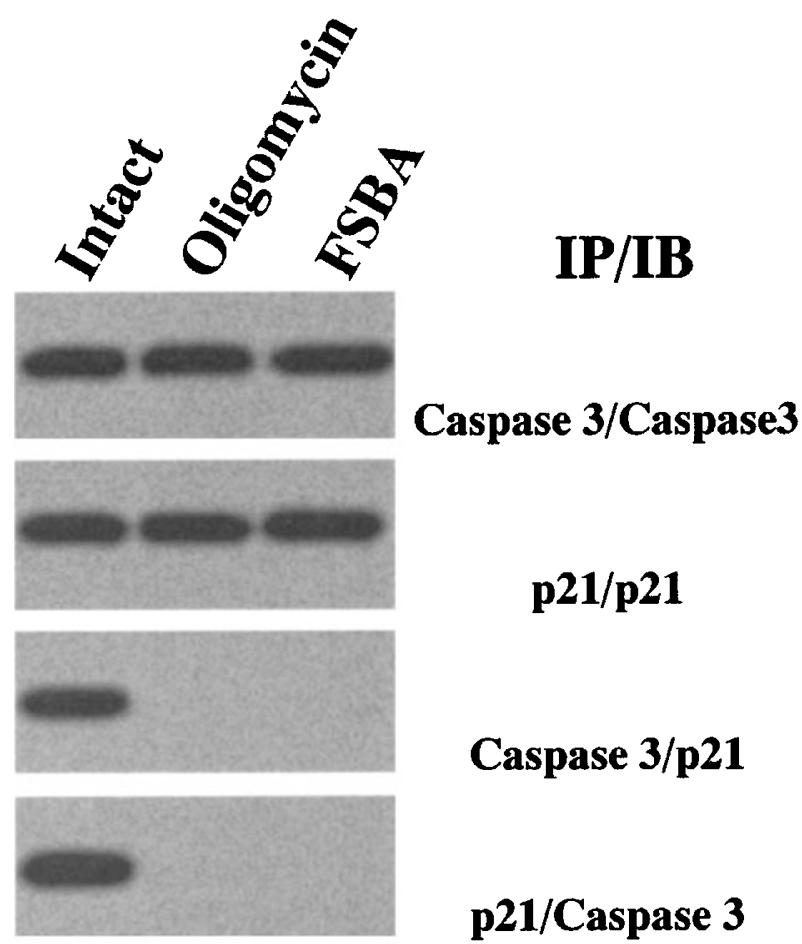

\section{Caspase 3/p21}

\section{p21/Caspase 3}

Figure 4 Effect of intracellular ATP-deprivation on procaspase 3/p21 complex formation. HepG2 cells were treated with or without (Intact) $10 \mu \mathrm{M}$ oligomycin or $100 \mu \mathrm{M}$ FSBA for $2 \mathrm{~h}$, and then proteins were extracted. Immunoprecipitates (IP) with antibody for caspase 3 or p21 were separated on $5-20 \%$ SDS-PAGE and caspase 3 or p21 was detected by immunoblotting (IB) with antibody for caspase 3 or p21 of membrane potential at an early stage during cell death induced by chemical hypoxia. ${ }^{20}$ In the current study, decreased mitochondrial membrane potential preceded Fas-mediated cell death. In addition, the ATP supply is generally known as essential to mitochondria, ${ }^{21-24}$ and we also observed decreased intracellular ATP levels before complete Fas-mediated cell death. In some cases of cell death induction, it has been reported that cytochrome $\mathrm{c}$ release as a result of mitochondrial damage acts as triggering system to activate caspase 9 (ICE-LAP6/Mch6/APAF-3 and see $^{19,25,26}$ ). In the current study, while mitochondrial damage was also observed during Fas-mediated cell death, we suggest that this mitochondrial damage is not involved with a transduction of Fas-initiated cell death signaling, since we have already demonstrated that HepG2 cells lacking mitochondria show Fas-mediated cell death. ${ }^{12}$ These observations raised the question of why the mitochondria were damaged at an early stage during Fas-mediated cell death. To address this issue, we investigated whether intracellular ATP-deprivation as a result of mitochondrial damage is involved with Fas-mediated cell death.

Recently, various researchers report the possible involvement of ATP-dependent steps in cell death signaling. Some report that an ATP-dependent pathway is involved with the exposure of phosphatidylserine to the outer cell membrane, a marker of apoptotic cell membrane damage, ${ }^{27-29}$ but not caspase activation. ${ }^{30}$ Others report that ATP is necessary for caspase 9-mediated cell death. ATP acts as an essential factor for the cytochrome c/Apaf-1 system ${ }^{25}$ which activates caspase-9. ${ }^{31}$ CED-4, which plays an important role in the induction of programmed cell death 


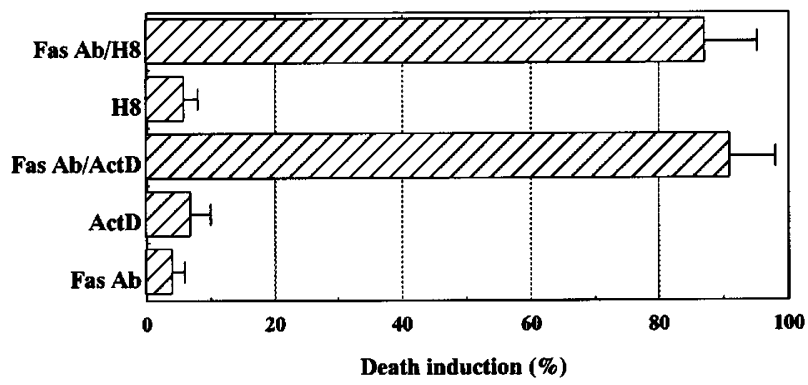

Figure 5 Effect of PKA in the resistance to Fas-mediated cell death. HepG2 cells were pretreated with $\mathrm{H} 8(10 \mu \mathrm{M})$ for $2 \mathrm{~h}$, and then Fas Ab treatment was performed at $1 \mu \mathrm{g} / \mathrm{ml}$ for $24 \mathrm{~h}$. After treatment, cells were stained with Hoechst $333422 / \mathrm{PI}$ and death induction was measured

Table 1 Effects of protein kinase inhibitor in Fas-mediated cell death

\begin{tabular}{|c|c|c|c|}
\hline Inhibitor & $\begin{array}{l}\text { Target } \\
\text { molecule }\end{array}$ & $\begin{array}{l}\text { Fas Ab/ActD } \\
\text { co-treatment }\end{array}$ & Fas $\mathrm{Ab}$ alone \\
\hline None & & Death & Live \\
\hline $\mathrm{H} 8$ & PKA & Death & Death \\
\hline PKB-BP & PKB & Death & Live \\
\hline BIM-I & $\mathrm{PKC}$ & Death & Live \\
\hline STP & PKC & Death & Live \\
\hline $\mathrm{HmA}$ & Tyrosine Kinase & Death & Live \\
\hline ML7 & MLCK & Death & Live \\
\hline KN62 & CaMK & Death & Live \\
\hline Dephostatin & PTP & Death & Live \\
\hline Tautomycin & PP1 & Death & Live \\
\hline Okadaic acid & PP2A & Death & Live \\
\hline Cypermethrin & PP2B & Death & Live \\
\hline PD98059 & MEK & Death & Live \\
\hline SB203580 & p38 & Death & Live \\
\hline SB202190 & p38 beta & Death & Live \\
\hline SB202474 & MAP kinase & Death & Live \\
\hline
\end{tabular}

PKA: protein kinase A; PKB: protein kinase B; PKC: protein kinase C; MLCK: myosin light chain kinase; CaMK: calmodulin kinase; PTP: protein tyrosine phosphatase; PP: protein phosphatase; MEK: MAP kinase kinase. HepG2 cells pretreated with each inhibitor at non-toxic dose for $2 \mathrm{~h}$ were incubated with agonist Fas $A b(1 \mu \mathrm{g} / \mathrm{ml})$ in the presence or absence of actinomycin $\mathrm{D}(0.5 \mu \mathrm{g} /$ $\mathrm{ml})$ for $24 \mathrm{~h}$

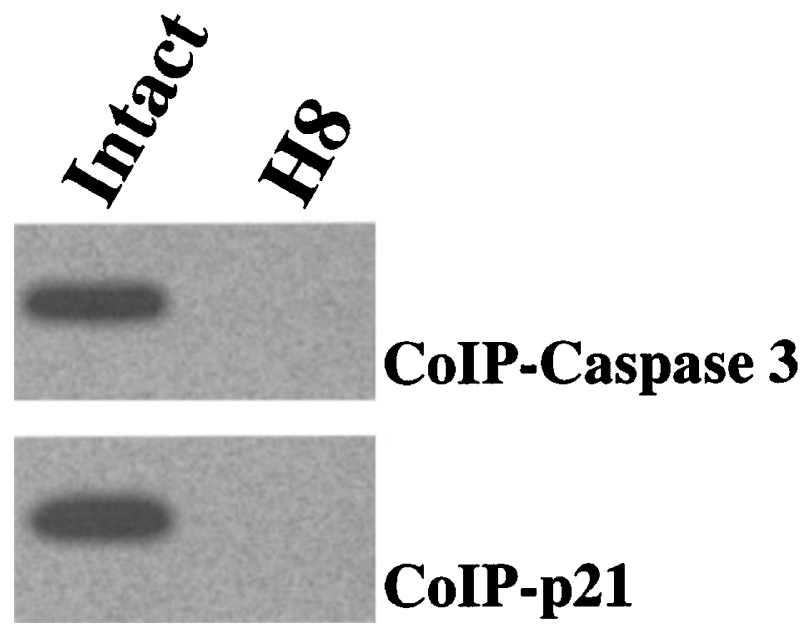

Figure 6 Effect of PKA on procaspase 3/p21 complex formation. HepG2 cells were treated with or without (Intact) $10 \mu \mathrm{M} \mathrm{H} 8$ for $2 \mathrm{~h}$, and then p21 Ab- or Caspase $3 \mathrm{Ab}$-immunoprecipitates were collected. Each immunoprecipitates were immunoreacted with antibody for caspase 3 (p21 IP/caspase 3 IB: ColP. Caspase 3) or p21 (caspase 3 IP/p21 IB: ColP-p21)
A

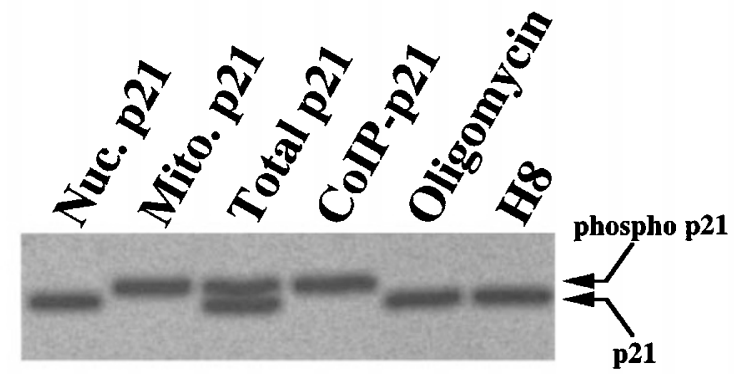

B

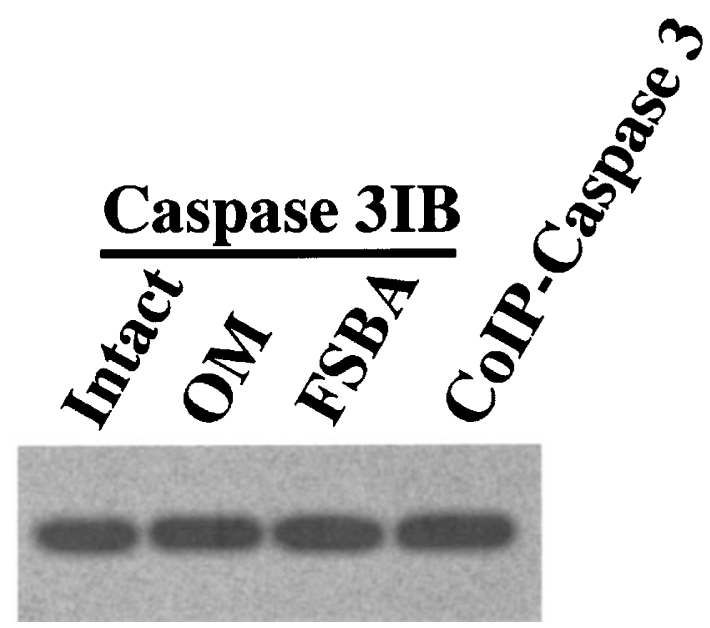

Figure 7 Phosphorylation of p21. (A) Phosphorylated p21 was detected as the molecular shift on 15\% SDS-PAGE. Fractionated proteins (nuclear proteins: Nuc. p21; mitochondrial proteins: Mito. P21), total proteins extracted from HepG2 cells treated with (Oligomycin or H8) or without (Total p21) inhibitor for $2 \mathrm{~h}$, and immunoprecipitates with caspase 3 antibody were separated on $15 \%$ SDS-PAGE, and then p21 was detected with immunoblotting procedure. Arrows show the position of phosphorylated (phospho p21) and un-phosphorylated (p21) p21. (B) Phosphorylation of procaspase 3 was also examined. Cells were treated with or without (Intact) oligomycin (OM) or FSBA, and proteins were extracted. Each cell extracts and p21 immunoprecipitates from intact cells were separated on $10 \%$ SDSPAGE, and then immunoblotting with caspase 3 antibody was performed

in Caenorhabditis elegans, ${ }^{32}$ also requires ATP for the induction of apoptotic cell death. ${ }^{33}$ In the present study, intracellular ATP-deprivation did not suppress Fasmediated cell death in HepG2 cells, suggesting that an ATP-dependent pathway does not exist in Fas-initiated death signaling of HepG2 cells. Ordinarily, HepG2 cells require an inhibitor for de novo protein synthesis, like actinomycin $\mathrm{D}$, to induce Fas-mediated cell death. ${ }^{10}$ However, our current work showed that intracellular ATPdeprivation could induce Fas-mediated cell death even in the absence of actinomycin $\mathrm{D}$. These results suggest that intracellular ATP is involved with the pathway conferring resistance to Fas-mediated cell death in HepG2 cells.

We have reported that caspase 3 , which is necessary for the induction of Fas-mediated cell death in HepG2 cells, is inactivated by two cellular factors. p21 interacts with only 


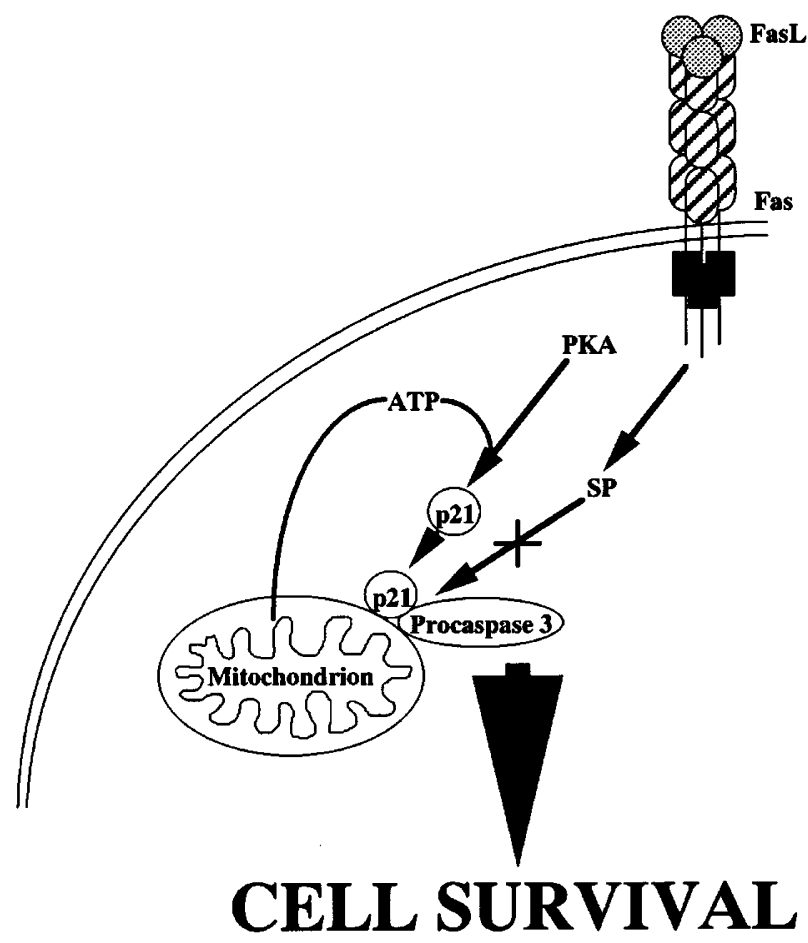

Figure 8 Schematic model of procaspase 3/p21 complex formation. Fas ligand (FasL)/Fas system induces the caspase 3 activation via cytoplasmic serine proteinase (SP and $s e e^{6}$ ) activation. However, since proteinasecleavage site on caspase $3^{6}$ is blocked by the interaction with p21 in cell, ${ }^{11}$ and Fas-mediated cell death is suppressed. ${ }^{10}$ Cellular protein kinase A (PKA) phosphorylates p21 using intracellular ATP supplied from mitochondrion. As a result of the phosphorylation of p21 by PKA, p21 interacts with procaspase 3 , and the complex acts as the cell survival system

the $\mathrm{NH}_{2}$-terminal sequence of the zymogen form of caspase 3 (procaspase 3 and see ${ }^{10,11}$ ). As a result of its interaction with $p 21$, the $\mathrm{p} 3$ cleavage site on procaspase 3 is blocked from cytoplasmic serine proteinase. ${ }^{6,11}$ Interestingly, mitochondria are also a necessity for procaspase 3/ p21 complex formation. ${ }^{12}$ In contrast, activated caspase 3 is suppressed by the IAP family member ILP. ${ }^{10}$ Thus, caspase 3 is inactivated by two systems in HepG2 cells. As indicated above, the procaspase 3/p21 complex formation is an interesting one, since mitochondria initiate its formation. ${ }^{12}$ ATP synthesis is the most well-known mitochondrial function. ${ }^{21}$ These observations suggest the possible involvement of an ATP-dependent pathway in mitochondrion-initiated cell survival, namely procaspase 3/ p21 complex formation. Our current study revealed that procaspase 3/p21 complex formation did not occur when cells were deprived of ATP. Since ATP-deprivation did not induce down-regulation of p21- or caspase 3-expression, our results indicate that intracellular ATP directly supports procaspase 3/p21 complex formation.

Our current observations suggested that procaspase 3/ p21 complex formation required an intracellular ATP and raised the possible involvement of protein kinase(s) in the complex formation. In addition, the phosphorylation of death-associated factors by protein kinases has been reported as the cell survival system. Protein kinase $B$ (PKB) family member Akt phosphorylates the Bcl-2 family member Bad which acts as the death accelerator, through PI-3 kinase/Akt signaling pathway. ${ }^{15,16,34,35}$ Recently, the phosphorylation of caspase 9 by Akt has been reported as one of cell survival system. ${ }^{17}$ On the other hand, ATP. dependent protein kinase PKA was reported as the cell survival factor. PKA also phosphorylate Bad to initiate cell survival. ${ }^{18}$ In the present study, an inactivation of PKA accelerated Fas-mediated cell death by the estrangement of procaspase 3/p21 complex formation, but PKB inhibitor did not. These results indicate that PKA regulates the procaspase 3/p21 complex formation as one of cell survival systems. In addition, we demonstrated p21, but not procaspase 3 , as the target molecule of PKA-phosphorylation. Since Fas-mediated cell death was suppressed by the procaspase 3-binding domain alone of p21, ${ }^{11}$ we suggest that PKA-phosphorylation site of p21 exists in the procaspase 3 -binding domain (Met $^{1}$-Lys $^{16}$ amino acid sequence). In addition, procaspase 3-binding domain contains two serine-residue $\left(\mathrm{Ser}^{2}\right.$ and $\left.\mathrm{Ser}^{15}\right)$. These two residues may be phosphorylated by PKA to form procaspase 3/p21 complex.

The human hepatoma HepG2 cell line is unique that it requires the de novo protein synthesis inhibitor actinomycin $\mathrm{D}$ for Fas-mediated cell death. ${ }^{10}$ This resistance results from caspase 3 inactivation by $\mathrm{p} 21$ and ILP. ${ }^{10}$ The procaspase 3/p21 complex formation is unique that it requires mitochondria. ${ }^{12}$ In the current study, we demonstrated that this mitochondrion-requirement is a necessity for the p21 phosphorylation initiated by PKA. We hypothesize the role of mitochondria in the procaspase $3 /$ p21 complex formation as follows (Figure 8). Mitochondria initiate the procaspase 3/p21 complex formation by the ATP supply. Using intracellular ATP, PKA phosphorylates p21, and the phosphorylated p21 interacts with procaspase 3 with $\mathrm{NH}_{2}$-terminal sequence on mitochondria to resist Fasmediated cell death. Here, we propose that procaspase 3/ p21 complex formation initiated by PKA and mitochondria is one of the important cell survival systems.

\section{Materials and Methods}

\section{Cell line and culture}

Human hepatoma HepG2 cells were supplied by Dr. Yoshihide Tsujimoto ${ }^{5}$ and were maintained in RPMI1640 medium (Gibco BRL, MD, USA) supplemented with $10 \%$ heat-inactivated fetal calf serum (FCS; Gibco BRL) in a humidified atmosphere of $5 \% \mathrm{CO}_{2}$ and $95 \%$ air.

\section{Peptides and chemicals}

DEVD-MCA was purchased from Peptide Lab. (Osaka, Japan). As the agonistic Fas antibody (Fas $\mathrm{Ab}$ ), the $\mathrm{CH}-11$ clone was purchased from MBL Japan (Nagoya). Staurosporine (STP), herbimycin A ( $\mathrm{HmA}), \mathrm{H} 8$, ML7, KN62, PKB blocking peptide (PKB-BP), bisindolylmaleimide I (BIM-I), cypermethrin, dephostatin, okadaic acid, tautomycin, PD98059, SB202190, SB203580 and SB202474 were purchased from Calbiochem-Novabiochem Corporation (La Jolla, CA, USA). 


\section{Protein extraction}

Proteins were prepared for immunoblotting and immunoprecipitation analysis by lysis of cells with $1 \%$ NP-40 containing buffer for $30 \mathrm{~min}$. All procedures were carried out at $4{ }^{\circ} \mathrm{C}$. Proteins were collected by the centrifugation at 15000 r.p.m. for 15 min. Protein concentrations were determined by a method described previously ${ }^{36,37}$ using the DC protein assay kit (Bio-Rad, CA, USA) with bovine serum albumin as standard.

\section{Preparation of cell extracts and assay of enzyme}

Preparation of cell extracts and assay of enzyme was performed as previously described ${ }^{5}$ with some modifications. ${ }^{10}$ Cells were collected, washed with PBS and suspended in PBS-EDTA ( $\mathrm{pH} 7.4)$. After the addition of $10 \mu \mathrm{M}$ digitonin (Sigma), cells were incubated at $37^{\circ} \mathrm{C}$ for $10 \mathrm{~min}$. Lysates were collected by centrifugation (15 000 r.p.m./5 min), and total protein concentration was determined using a DC protein assay kit (Bio Rad). For enzyme assay, aliquots were incubated with $10 \mu \mathrm{l}$ DEVD-MCA $(50 \mu \mathrm{M})$, and the release of amino-4-methylcoumarin was monitored with a spectrofluorometer. One unit was defined as the amount of enzyme required to release $0.22 \mathrm{nmol} A M C$ per min at $37^{\circ} \mathrm{C}$.

\section{Immunoblotting analysis}

Sample proteins separated by SDS-PAGE were transferred onto nitrocellulose membranes with a semi-dry blotting system. The membranes were blocked with PBS containing $5 \%(\mathrm{w} / \mathrm{v})$ skim milk at room temperature for $1 \mathrm{~h}$, washed with a mixture of PBS and $0.05 \%$ Tween 20 (Sigma, Tween-PBS), and then incubated overnight at room temperature with each antibody diluted with PBS. After washing with Tween-PBS, the membranes were incubated with a 1000-fold diluted biotinylated anti-mouse IgG antibody (Bio Source, CA, USA), washed with Tween-PBS, and then incubated with avidin-HRP (Vector Lab., $\mathrm{CA}$, USA) at room temperature for $1 \mathrm{~h}$. The membranes were washed with Tween-PBS and then developed with the ECL system.

\section{Immunoprecipitation analysis}

Anti-caspase 3 antibody (Transduction Lab., KY, USA) or anti p21 antibody (Santa Cruz, CA, USA) was mixed with $1 \mathrm{mg}$ protein from each cell extract for $30 \mathrm{~min}$. Protein A-sepharose was then added and incubated for $2 \mathrm{~h}$. The immunoprecipitates were heated in SDS sample buffer and separated on 5-20\% polyacrylamide gels. After transfer, the membranes were immunoblotted, washed with Tween-PBS and developed using the ECL system (Amersham, Buckinghamshire, UK).

\section{Assay of cell viability}

Cell viability of each group was assessed by the Hoechst 33342/ propidium iodide $(\mathrm{PI})$ staining procedure as previously described ${ }^{5}$ with some modifications. ${ }^{6,38}$ Hoechst 33342 and PI were purchased from Molecular Probes, Inc. (OR, USA). After treatment, cells were stained with the mixture of Hoechst 33342 and PI, and then observed by fluorescence microscopy. Cell viability was indicated by the ratio of cells carrying intact nuclei to total cells (about 5000 cells).

\section{Acknowledgments}

We thank Dr. Yoshihide Tsujimoto, Osaka University Medical School, for human hepatoma HepG2 cells, and Dr. Masayuki Miura, Osaka University of Medical School, for his valuable discussions. The preparation of this manuscript was supported by the Idest Inc., Edmond, OK, USA.

\section{References}

1. Wyllie AH, Kerr JFR and Currie AR (1980) Cell death: The significance of apoptosis. Int. Rev. Cytol. 68: 251-306

2. Nagata S (1997) Apoptosis by death factor. Cell 88: 355-365

3. Nagata $S$ and Golstein P (1995) The Fas death factor. Science 267: 1449- 1456

4. Alnemri ES, Livingston DJ, Nicholson DW, Salvesen G, Thornbery NA, Wong WW and Yuan J (1996) Human ICE/CED-3 protease nomenclature. Cell 87: 171

5. Hasegawa J, Kamada S, Kamiike W, Shimizu S, Imazu T, Matsuda H and Tsujimoto Y (1996) Involvement of CPP32/Yama(-like) proteases in Fasmediated apoptosis. Cancer Res. 56: 1713-1718

6. Suzuki A, Iwasaki M and Wagai N (1997) Involvement of cytoplasmic serineproteinase and CPP32 subfamily in the molecular machinery of caspase 3 activation during Fas-mediated apoptosis. Exp. Cell. Res. 233: 48-55

7. Muzio M, Chinnaiyan AM, Kischkel FC, O'Rourke K, Shevchenko A, Ni J, Scaffidi C, Bretz JD, Zhang M, Gentz R, Mann M, Krammer PH, Peter ME and Dixit VM (1996) FLICE, a novel FADD-homologous ICE/CED-3-like protease, is recruited to the CD95 (Fas/APO-1) death-inducing signaling complex. Cell 85: 817-827

8. Boldin MP, Goncharov TM, Golstev YV and Wallach D (1996) Involvement of MACH, a novel MORT-1/FADD-interacting protease, in Fas/APO-1 and TNF receptor-induced cell death. Cell 85: 803-815

9. Thornbery NA, Rano TA, Peterson EP, Rasper DM, Timkey T, Garcia-Calvo M, Houtzager VM, Nordstorm PA, Roy S, Vaillancourt JP, Chapman KT and Nicholson DW (1997) A combinatorial approach defined specifities of members of the caspase family and granzyme B: Functional relationships established for key mediators of apoptosis. J. Biol. Chem. 272: 17907-17911

10. Suzuki A, Tsutomi Y, Akahane K, Araki T and Miura M (1998) Resistance to Fasmediated apoptosis: Activation of caspase 3 is regulated by cell cycle regulato p21WAF1 and IAP gene family ILP. Oncogene 17: 931-940

11. Suzuki A, Tsutomi Y, Miura M and Akahane K (1999) Caspase 3 inactivation to suppress Fas-mediated apoptosis: Identification of binding domain with p21 and ILP, and inactivation machinery by p21. Oncogene 18: 1239-1244

12. Suzuki A, Tsutomi Y, Yamamoto N, Shibutani T and Akahane K (1999) Mitochondrial regulation of cell death: Mitochondria are essential for procaspase 3/p21 complex formation to resist Fas-mediated cell death. Mol. Cell. Biol. 19: 3842-3847

13. DuckettCS, Nava VE, Gedrich RW, Clem RJ, Dongen JLV, Gilfillan MC, Shiels H, Hardwick JM and Thompson CB (1996) A conserved family of cellular genes related to the baculovirus iap gene and encoding apoptosis inhibitors. EMBO J. 15: $2685-2694$

14. Deveraux QL, Takahashi R, Salvesen GS and Reed JC (1997) X-linked IAP is a direct inhibitor of cell death proteases. Nature 388: 300-304

15. Peso L, Gonzalez-Garcia M, Page C, Herrera Rand Nunez G (1997) Interleukin3 -induced phosphorylation of BAD through protein kinase Akt. Science 278 687-689

16. Datta SR, Dudek H, Tao X, Masters S, Fu H, Gotoh Y and Greenberg ME (1997) Akt phosphorylation of Bad couples survival signals to the cell-intrinsic death machinery. Cell 91: 231-241

17. Cardone MH, Roy N, Stennicke HR, Salvesen GS, Franke TF, Stanbridge E, Frisch S and Reed JC (1998) Regulation of cell death protease caspase-9 by phosphorylation. Science 282: 1318-1321

18. Harada H, Becknell B, Wilm M, Mann M, Huang LJ, Taylor SS, Scott JD and Korsmeyer SJ (1999) Phosphorylation and inactivation of BAD by mitochondriaanchored protein kinase A. Mol. Cell. 3: 413-422

19. Green DR and Reed JC (1998) Mitochondria and apoptosis. Science 281 $1309-1312$

20. Shimizu S, Eguchi Y, Kamiike W, Waguri S, Uchiyama $\mathrm{Y}$, Matsuda $\mathrm{H}$ and Tsujimoto Y (1996) Bcl-2 blocks loss of mitochondrial membrane potential while ICE inhibitors act at a different step during inhibition of death induced by respiratory chain inhibitors. Oncogene 13: 21-29

21. Margulis L (1975) Symbiotic theory of the origin of eukaryotic organelles; criteria for proof. Symp. Soc. Exp. Biol. 29: 21-38

22. Desjardins $P$, Frost $E$ and Morais R (1985) Ethidium bromide-induced loss of mitochondrial DNA from primary chicken embryo fibroblasts. Mol. Cell. Biol. 5 $1163-1169$ 
23. King MP and Attardi G (1989) Human cells lacking mtDNA: Repopulation with exogenous mitochondria by complementation. Science 246: 500-503

24. Jacobson MD, Burne JF, King MP, Miyashita T, Reed JC and Raff MC (1993) Bcl2 blocks apoptotis in cells lacking mitochondrial DNA. Nature 361: 365-369

25. Zou H, Henzel WJ, Liu X, Lutschg A and Wang X (1997) Apaf-1, a human protein homologous to $\mathrm{C}$. elegans CED-4, participates in cytochrome c-dependent activation of caspase-3. Cell 90: 405-413

26. Liu X, Kim CN, Yang J, Jemmerson R and Wang X (1996) Induction of apoptotic program in cell-free extracts: Requirement for dATP and cytochrome c. Cell 86: $147-157$

27. Fadok VA, Voelker DR, Campbell PA, Cohen JJ, Bratton DL and Henson PM (1992) Exposure of phosphatidylserine on the surface of apoptotic lymphocytes triggers specific recognition and removal by macrophages. J. Immunol. 148: 2207-2216

28. Mower Jr DA, Peckham DW, Illera VA, Fishbaugh JK, Stunz LL and Ashman RF (1994) Decreased membrane phospholipid packing and decreased cell size precede DNA cleavage in mature mouse B cell apoptosis. J. Immunol. 152: $4832-4842$

29. Martin SJ, Reutelingsperger CP, McGahon AJ, Rader JA, van Schie RC, LaFace DM and Green DR (1995) Early redistribution of plasma membrane phosphatidylserine is a general feature of apoptosis regardless of the initiating stimulus: inhibition by overexpression of Bcl-2 and Abl. J. Exp. Med. 182: 15451556

30. Zhuang J, Ren Y, Snowden RT, Zhu H, Gogvadze V, Savill JS and Cohen GM (1998) Dissociation of phagocyte recognition of cells undergoing apoptosis from other features of the apoptotic program. J. Biol. Chem. 273: 15628-15632
31. Eguchi Y, Srinivasan A, Tomaselli KJ, Shimizu S and Tsujimoto Y (1999) ATPdependent steps in apoptotic signal transduction. Cancer Res. 59: 2174-2181

32. Yuan J and Horvitz HR (1992) The Caenorhabditis elegans cell death gene ced-4 encodes a novel protein and is expressed during the period of extensive programmed cell death. Development 116: 309-320

33. Kanuka H, Hisahara S, Sawamoto K, Shoji S, Okano H and Miura M (1999) Proapoptotic activity of Caenorhabditis elegans CED-4 protein in Drosphila: Implicated mechanism for caspase activation. Proc. Natl. Acad. Sci. USA 96: $145-150$

34. Kennedy SG, Wagner AJ, Conzen SD, Jordan J, Bellacosa A, Tsichlis PN and Hay N (1997) The PI 3-kinase/Akt signaling pathway delivers an anti-apoptotic signal. Genes Dev. 11: 701-713

35. Ahmed NN, Grimes HL, Bellacosa A, Chang TO and Tsichlis PN (1997) Transduction of interleukin-2 antiapoptotic and proliferative signals via Akt protein kinase. Pro. Natl. Acad. Sci. USA 94: 3627-3632

36. Hill HD and Sraka J (1988) Protein determination using bicinchoninic acid in the presence of sulfhydryl reagents. Anal. Biochem. 170: 203-208

37. Smith PK, Krohn RI, Hermanson GT, Mallia AK, Gartner FH, Provenzano MD, Fujimoto EK, Goeke NM, Olson BJ and Klenk DC (1985) Measurement of protein using bicinchoninic acid. Anal. Biochem. 170: 203-208

38. Suzuki A, Iwasaki M, Kato M and Wagai N (1997) Sequential operation of ceramide synthesis and ICE cascade in CPT-11-initiated apoptotic death signaling. Exp. Cell Res. 233: 41-47

39. Yonehara S, Ishii A and Yonehara M (1989) A cell killing monoclonal antibody (anti-Fas) to a cell surface antigen co-downregulated with the receptor of tumor necrosis factor. J. Exp. Med. 169: 1747-1756 